\title{
Properties of elastomeric compositions with sonicated superfine carbon additives
}

\author{
Zhanna S. Shashok ${ }^{1)}$, Nikolai R. Prokopchuk ${ }^{1)}$, Konstantin V. Vishnevskii ${ }^{1)}$, Igor V. Voitov ${ }^{11}$, \\ Marek Opielak ${ }^{2), *)}$, Paweł Zukowski ${ }^{3)}$
}

DOI: dx.doi.org/10.14314/polimery.2017.728

\begin{abstract}
The influence of superfine carbon additives and their pretreatment by ultrasonication on the properties of elastomer compositions has been investigated. Superfine carbon additives come in two different types: fullerene-containing additives and ultra fine carbon additives (a complex mixture of nanofibers and nanotubes, graphite and amorphous carbon particles). Mooney viscosity, parameters of relaxation and vulcanization kinetics of rubber mixtures, tensile strength, elongation at break and resistance to thermal aging, abrasion resistance and compression of filled rubbers based on butadiene-acrylonitrile were carried out. Except for the identified characteristics, crosslink parameters by the method of equilibrium swelling were determined. It was found that the introduction of the ultrasonically pretreated, superfine carbon additives to elastomeric compositions based on butadiene-acrylonitrile rubber led to rubber with improved thermo-oxidative and wear resistance in comparison to rubbers containing untreated additives.
\end{abstract}

Keywords: elastomeric compositions, rubber, carbon nanofillers.

\section{Właściwości kompozycji elastomerowych z drobnymi dodatkami węglowymi poddanymi sonikacji}

\begin{abstract}
Streszczenie: Wykonano badania wpływu drobnych dodatków węglowych i ich wstępnej obróbki ultradźwiękami na właściwości kompozycji elastomerowych na bazie kauczuku butadienowo-akrylonitrylowego. Zastosowano dwa rodzaje drobnych dodatków węglowych: dodatek zawierający fulereny oraz wysoko zdyspergowany dodatek stanowiący mieszaninę złożoną z nanowłókien, nanorurek, grafitu oraz amorficznych cząstek węgla. Wyznaczono lepkość Mooney'a, parametry relaksacji i kinetykę wulkanizacji mieszanek gumowych, a metodą pęcznienia równowagowego określono gęstość usieciowania wulkanizatów. Zbadano także wytrzymałość na rozciąganie, odkształcenie przy zerwaniu, odporność na starzenie cieplne oraz odporność na ścieranie i ściskanie napełnionych gum.
\end{abstract}

Słowa kluczowe: kompozyty elastomerowe, guma, nanonapełniacze węglowe.

The properties of elastomeric compositions can be significantly improved by using highly-dispersed components of different chemical nature, size, and specific surface areas. At the moment, of great scientific and practical interest is the use of rubber carbon nanofillers, which possess a specific set of properties: high reactivity, defined small particle size, and presence of a large number of functional groups on the surface. Because of the ten-

1) Belarusian State Technological University, Sverdlov Str. 13a, 220006 Minsk, Belarus.

2) Institute of Transport, Combustion Engines and Ecology, Lublin University of Technology, Nadbystrzycka 36, 20-618 Lublin, Poland.

3) Department of Electrical Devices and High Voltage Technology, Lublin University of Technology, Nadbystrzycka 38a, 20-618 Lublin, Poland.

*) Author for correspondence; e-mail: marek.opielak@gmail. com dency of self-association in nanostructures (fullerenes, nanotubes, and nanofibers), the use of such substances to modify the properties of the elastomer is refrained [1-6]. Therefore, the main problem in the manufacturing of elastomeric nanocomposites is the dissociation of agglomerates into nanostructures and their uniform distribution in the polymer matrix. The method of ultrasonic processing of the nanostructured agglomerates is used to obtain their maximum possible specific surface [7-11].

The aim of this work was to determine the effect of the sonicated superfine carbon additives on the properties of elastomeric compositions made of nitrile rubber.

\section{EXPERIMENTAL PART}

\section{Materials}

Filled rubbers based on raw rubber for special application were investigated. The main component was a buta- 
diene-acrylonitrile rubber (trade name BNKS-28), which contains $27-30$ wt \% of bound acrylonitrile. As a filler, a combination of semi-active (N550) and inactive types of carbon black (N772) were used in the amount of 15 and 60 phr, respectively.

The curing system consisted of sulfur (2.2 phr) and accelerator, which was $\mathrm{N}$-cyclohexylbenzothiazole-2-sulfenamide (CBS, 1.7 phr). Additional additives were used: zinc oxide (5 phr), stearic acid (1 phr), dibutylphthalate as a plasticizer (32 phr), and anti-deteriorating agent ( $3 \mathrm{phr}$ ).

Two kinds of ultra fine carbon additives at a dosage of 0.20 phr were added into the rubber mix formulation. Samples without ultra fine additives in their composition served as reference samples. Mixtures were made in a laboratory mixer.

Fullerene-containing additive (FCA) is a fullerene-containing carbon black, which was obtained from the hardware LLC "FizTehPribor" at the Ioffe Physical-Technical Institute (St. Petersburg). The results from high performance liquid chromatography revealed that this additive contains $5 \%$ of fullerene in a mass ratio $C_{60} / C_{70}=2.6$. The specific surface of the FCA was $180-200 \mathrm{~m}^{2} / \mathrm{g}$ (determined using the BET method).

Ultra fine carbon additive (UFCA) is a complex mixture of relatively large structures, such as tangles of carbon nanofibers and nanotubes, graphite formation, amorphous carbon particles, etc. It had a specific surface in accordance of the BET method of $200-220 \mathrm{~m}^{2} / \mathrm{g}$. This kind of fine-grained carbon material is produced by Advanced Research and Technology (Minsk) with the trade name "ART-NANO” (TU BY690654933.001-2011).

\section{Methods of testing}

The properties of the prepared compositions were determined using rotational viscosimetry (Mooney viscometer MV 2000, Alpha Technologies) in accordance with the ASTM D1646-07 standard. The relaxation coefficient $\left(K_{p}\right)$ was calculated as a percent of the Mooney viscosity $\left[\mathrm{ML}(1+4)\right.$ at $\left.100{ }^{\circ} \mathrm{C}\right]$ of residual torque $1 \mathrm{~s}$ after the rotor stopped (Intercept). The slope of the tangent to the curve of the relaxation after $1 \mathrm{~s}$ after the stopping of the rotor $(\operatorname{tg} \alpha$ ') was also determined. Vibration rheometry (oscillating disc rheometer ODR 2000, Alpha Technologies), in accordance with the ASTM D2084-11 standard, was used to determine the vulcanization characteristics. The tensile properties, abrasion resistance and compression set were determined using methods regulated in the GOST 270-75, GOST 426-77, and GOST 9.029-74 standards, respectively, using a Universal Tester T2020 DC (Alpha Technologies). All vulcanized samples were swollen by toluene to calculate their crosslink densities through the Flory-Rehner equation:

$$
\frac{1}{M_{c}}=\frac{V_{r}+\chi \cdot V_{r}^{2}+\ln \left(1-V_{r}\right)}{\varrho_{r} \cdot V_{0} \cdot\left(V_{r}^{1 / 3}-0.5 \cdot V_{r}\right)}
$$

where: $M_{c}$ - average molar mass of the molecular chain between the two crosslinks, $V_{0}=106.3 \mathrm{~cm}^{3} / \mathrm{mol}$ - the mo- lar volume of utilized solvent, $\mathrm{Q}_{r}$ - density of raw rubber, $V_{r}$ - the volume fraction of polymer in the swollen sample, $\chi$ - the Flory-Huggins polymer-solvent interaction parameter or the enthalpy of mixing.

The value of $\chi$ may be found in the literature or determined by the following equation:

$$
\chi=\beta_{1}+\frac{V_{0}\left(\delta_{1}-\delta_{2}\right)^{2}}{R T}
$$

where: $\beta_{1}$ - the lattice constant of entropic origin (often assumed to be zero), $T$ - the medium temperature, $\delta_{1}=18.2 \mathrm{MPa}^{0.5}, \delta_{2}=19.0 \mathrm{MPa}^{0.5}$ - solubility parameters for the solvent and BNKS-28 rubber, respectively.

The crosslink density was determined from the density of rubber (@) using equation:

$$
v=\frac{\varrho}{M_{c}}
$$

The resistance to thermal aging $(K)$ at $125^{\circ} \mathrm{C}$ over $72 \mathrm{~h}$ was evaluated by comparison of the elastic-strength properties (tensile strength and elongation at break) determined before and after aging. On the basis of this data, the aging coefficients were calculated:

$$
K=\frac{A_{1}}{A_{0}}
$$

where: $A_{0}$ - property value before aging, $A_{1}$ - property value after aging.

Ultrasonic processing of the additives was carried out at $20^{\circ} \mathrm{C}$ on an ultrasonic cleaner pc-08a (ultrasonic power was $70 \mathrm{~W}$ and processing time $30 \mathrm{~min}$ ).

Statistical processing of the results of measurements was carried out using the program Statistica 5.5. The relative errors for the main measured parameters are listed in Table 1.

$\mathrm{T}$ a $\mathrm{b}$ l e 1 . The relative errors of determined parameters

\begin{tabular}{l|c}
\hline \multicolumn{1}{c|}{ Parameter } & Relative error, \% \\
\hline $\begin{array}{l}\text { Mooney viscosity of rubber } \\
\text { mixtures }\end{array}$ & 2 \\
$\begin{array}{l}\text { The time to reach an optimal } \\
\text { degree of vulcanization } \\
\text { Torque }(M L \text { and } M H)\end{array}$ & 2 \\
$\begin{array}{l}\text { Conventional stress at } 100 \% \text { of } \\
\text { elongation }\end{array}$ & 2 \\
Tensile strength & 6 \\
Elongation at break & 6 \\
Crosslink density & 6 \\
Abrasion resistance & 7 \\
Compression set & 5 \\
\hline
\end{tabular}

\section{RESULTS AND DISCUSSION}

One of the main indicators to evaluate the processability of rubber compounds is the viscosity according to Mooney. The viscosity of the processed material determines the dynamics of the processing because it is a 
T a b l e 2. Mooney viscosity of the elastomeric compositions tested by viscometer MV 2000

\begin{tabular}{l|c|c|c|c}
\hline \multicolumn{1}{c|}{ Type of the additive } & $\begin{array}{c}\text { Dosage of additive } \\
\mathrm{phr}\end{array}$ & $\begin{array}{c}\text { Mooney viscosity of composition } \\
\text { Mooney unit }\end{array}$ & $\operatorname{tg} \alpha^{\prime}$ & $K_{p^{\prime}} \%$ \\
\hline Without additives & - & 111.0 & -0.395 & 55.6 \\
\hline \multirow{2}{*}{ FCA } & 0.2 & 107.9 & -0.405 & 56.4 \\
\hline \multirow{2}{*}{ UFCA } & 0.2 (sonicated) & 109.1 & -0.410 & 56.2 \\
\hline
\end{tabular}

measure of the force that must be applied to the material for its flow at a given speed at a certain stage of the process [12]. The use of fine additives in the elastomeric compositions, even in small amounts, may influence the elastoplastic properties of rubber mixtures and, above all, the Mooney viscosity. The results of the research listed in Table 2 show that the introduction of superfine additives of various structures leads to some reduction of the Mooney viscosity (1-4\%).

The effects of ultrasound treatment of fullerene-containing additive on the viscosity of compositions was not important (the maximal change of the viscosity was between 106.5 and 109.4 Mooney units). In the case of treatment by ultrasound of FCA, the viscosity of the rubber composition slightly increases in comparison with compositions containing this additive without treatment (from 107.9 to 109.1 Mooney units). In the case of compositions containing UFCA, sonication of the additive causes some reduction in the Mooney viscosity (by $2.6 \%$, i.e., 2.9 Mooney units).

Such behavior of the properties may be due to the structure and form of agglomerated nanoparticles. Ultrasonic treatment helps to dissociate and better disperse the investigated components in a volume of the elastomeric matrix. This can lead to a relieved orientation of the molecules in the direction of flow and decrease the Mooney viscosity of rubber compounds, as well as accelerate the relaxation processes in the volume of the elastomeric matrix after removal of the load. This assumption is supported by the increase in the relaxation rate $(\operatorname{tg} \alpha$ in Table 2). At the same time, increasing the contact surface between rubber and particles in the case of sonicated fullerene additives leads to difficulties in the flow of the polymeric material. Perhaps this is due to the interaction between functional groups of the polymer and investigated additives.

Superfine carbon additives have large values of specific surface and functional groups may participate in the curing process and form chemical and physical bonds at different stages of the process, as well as in interactions with the components of the vulcanization system. The parameters of vulcanization (carried out at $153^{\circ} \mathrm{C}$ ) of elastomeric compositions based on BNKS-28, filled with carbon additives, are collected in Table 3.

The data show that the use of additives in the elastomeric composition has some influence on the kinetics of vulcanization of the rubber mixtures. The introduction of FCA and UFCA without ultrasonic pretreatment leads to a reduction in the time necessary to reach an optimal degree of vulcanization by $4-7 \%$. Using ultrasonic pretreated UFCA leads to an increase in this parameter of $6 \%$ in comparison with the sample without additives. Such an effect of the additives on the structuring process is connected apparently with their ability to participate in the decay and recombination reactions of radicals of the vulcanizing components. Formed during the decay of vulcanizing agents, radicals can react with active additives, wherein the crosslinking of macromolecules goes through a series of intermediate reactions [13].

Ultrasonic treatment of superfine carbon additives can lead to the formation of defective areas with uncompensated bonds, which gives the surface of nanoadditives new properties and accelerates the processes of adsorption on their surface [14]. This, in turn, may influence the formation of crosslinks between rubber macromolecules.

$\mathrm{T}$ a b l e 3. Parameters of the vulcanization of the rubber compositions at $153^{\circ} \mathrm{C}$

\begin{tabular}{l|c|c|c|c|c|c|c}
\hline \multicolumn{1}{c|}{ Type of the additive } & $\begin{array}{c}\text { Dosage of additive } \\
\mathrm{phr}\end{array}$ & $\begin{array}{c}M L^{\mathrm{a}} \\
\mathrm{dH} \cdot \mathrm{m}\end{array}$ & $\begin{array}{c}M H^{\mathrm{b}} \\
\mathrm{dH} \cdot \mathrm{m}\end{array}$ & $\begin{array}{c}t_{S 2}^{\mathrm{c}} \\
\mathrm{min}\end{array}$ & $\begin{array}{c}t_{50}^{\mathrm{d})} \\
\mathrm{min}\end{array}$ & $\begin{array}{c}t_{90}^{\mathrm{e})} \\
\mathrm{min}\end{array}$ & $\begin{array}{c}\Delta S^{\mathrm{f}} \\
\mathrm{dH} \cdot \mathrm{m}\end{array}$ \\
\hline Without additives & - & 12.6 & 68.9 & 3.7 & 4.7 & 9.1 & 56.3 \\
\hline \multirow{2}{*}{ FCA } & 0.2 & 12.0 & 68.5 & 3.5 & 4.5 & 8.5 & 56.5 \\
& 0.2 (sonicated) & 12.5 & 68.9 & 3.5 & 4.4 & 8.7 & 56.4 \\
\hline \multirow{2}{*}{ UFCA } & 0.2 & 12.6 & 69.6 & 3.5 & 4.5 & 8.8 & 57.0 \\
& 0.2 (sonicated) & 12.0 & 68.3 & 3.5 & 4.5 & 9.6 & 56.3 \\
\hline
\end{tabular}

a) $M L$ - minimal torque, ${ }^{\text {b) }} M H$ - maximal torque, ${ }^{\text {c) }} t_{S 2}$ - the time required to increase the minimum torque at 2 units, ${ }^{\text {d) }} t_{50}-$ the time to reach a set degree of cure, e) $t_{90}$ - the time to reach an optimal degree of vulcanization, ${ }^{\text {f) }} \Delta S$ - the difference between maximal and minimal torque. 
$\mathrm{T}$ a b l e 4 . Changes to strength properties of the rubbers under aging by heating in air

\begin{tabular}{|c|c|c|c|c|c|c|c|}
\hline \multirow{2}{*}{$\begin{array}{c}\text { Type of the } \\
\text { additive }\end{array}$} & \multirow{2}{*}{$\begin{array}{c}\text { Dosage of } \\
\text { additive } \\
\text { phr }\end{array}$} & \multicolumn{2}{|c|}{$\begin{array}{l}S_{100} \\
\mathrm{MPa}\end{array}$} & \multicolumn{2}{|c|}{$\begin{array}{c}T S \\
\mathrm{MPa}\end{array}$} & \multicolumn{2}{|c|}{$\begin{array}{l}\varepsilon_{b} \\
\%\end{array}$} \\
\hline & & before aging & after aging & before aging & after aging & before aging & after aging \\
\hline $\begin{array}{l}\text { Without } \\
\text { additives }\end{array}$ & - & 5.9 & 12.0 & 14.1 & 14.7 & 250 & 120 \\
\hline \multirow[b]{2}{*}{ FCA } & 0.2 & 10.0 & 13.5 & 14.7 & 15.4 & 240 & 130 \\
\hline & $\begin{array}{c}0.2 \\
\text { (sonicated) }\end{array}$ & 10.4 & 13.3 & 14.4 & 15.4 & 210 & 130 \\
\hline \multirow[b]{2}{*}{ UFCA } & 0.2 & 8.0 & 13.7 & 15.3 & 15.9 & 230 & 120 \\
\hline & $\begin{array}{c}0.2 \\
\text { (sonicated) }\end{array}$ & 9.4 & 14.7 & 14.7 & 15.5 & 220 & 120 \\
\hline
\end{tabular}

Crosslinked rubber during deformation is characterized by a predominance of the elastic deformation over the plastic one. To evaluate the elastic-strength characteristics, conventional stress at $100 \%$ of elongation $\left(S_{100}\right)$, tensile strength $(T S)$ and elongation at break $\left(\varepsilon_{b}\right)$ were determined and changes in these parameters after thermal aging were measured. The results of the strength properties before and after aging of cured rubbers based on BNKS-28, containing superfine carbon additives, are listed in Table 4.

The analysis of strength-elongation properties of rubber without thermal aging showed that the application of superfine carbon additives makes $S_{100}$ grow by 1.36-1.76 times compared to samples without the additive. At the same time, the tensile strength does not differ substantially. Comparative analysis of strength properties after thermal aging showed that high temperatures in the bulk of the elastomeric matrix lead to dominated structuring processes. This increases the strength of rubber but causes the loss of its elastic properties. It should be noted that in the case of the sample without additives, the $S_{100}$ value was lower by 11-22\% in comparison with rubbers containing the investigated additives. It is known [15] that one of the determining factors to obtain rubber with high strength properties is the nature and regularity of the distribution of crosslinks in the amount of vulcanizate. In this case, higher values of $S_{100}$ of the rubbers with superfine carbon additives may be associated with higher crosslink densities of the elastomer and with the spatial grid of defects, which contributes to the relaxation of local overstrain and the orientation of the material at the moment of breaking.

On the basis of the data obtained before and after thermal aging, aging coefficients $(K)$ were calculated, allowing the assessment of the effect of superfine additives on the resistance of rubbers to high temperatures. The results are presented in Fig. 1.

The data show, that the use of superfine carbon additions in the elastomeric compositions allows some increase in their resistance to thermo-oxidative aging. At the same time, it should be noted that a rubber with the ultrasonically pretreated additives is less prone to changes in elastic and tensile properties under aggressive factors. Changing of the properties of rubber during ther- mal aging is associated primarily with features of the spatial structure formed during the vulcanization of the rubber mixture.

In this regard, parameters of the vulcanization network by equilibrium swelling, using the Flory-Rehner equation [16], were determined and are listed in Table 5.

The results show that rubbers with the addition of superfine carbon additives have higher crosslink densities, both before and after thermal aging, which correlates with the $S_{100}$ of elongation and thermal resistance (K coefficient) data.

Increasing the concentration of crosslinking, probably due to the occurrence of a more complete curing process, is likely to be in response to interactions of additives with components of the rubber mixture. It should be noted that ultrasonic pretreatment of superfine carbon additives allows rubbers with lower crosslinking density but more resistant to oxidative aging. In this case, in addition to a more uniform distribution of the additive in the elastomeric matrix, physical bonds, the same as thixotropic structures, may be formed due to the interaction between polar groups of rubber and active centers of the additive. Intense ultrasonic treatment is an effective method of surface modification of superfine carbon additives [14], which allows us to better ensure these in-

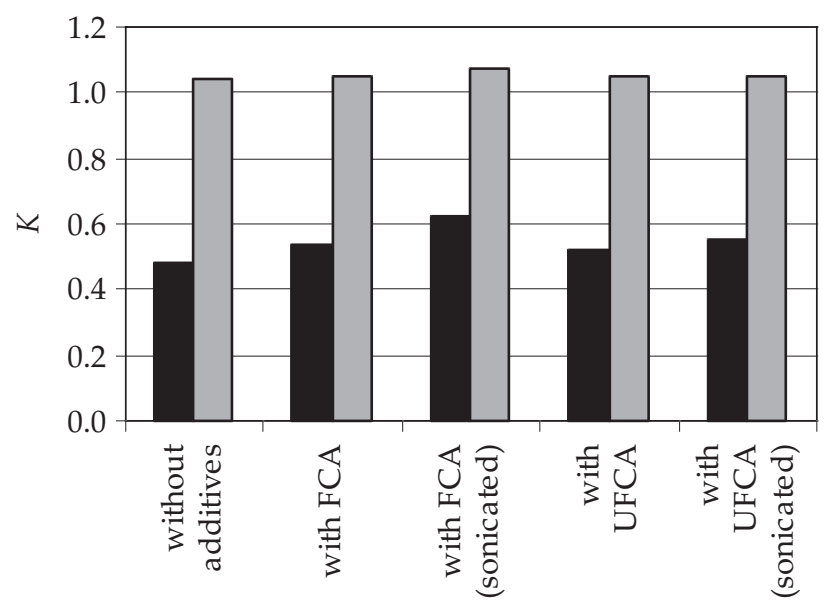

W by tensile strength $\quad \square K$ by elongation at break

Fig. 1. Aging coefficient $(K)$ of rubbers calculated from values of tensile strength and elongation at break 
$\mathrm{T}$ a b l e 5. Parameters of the vulcanization network of the rubber compositions

\begin{tabular}{|c|c|c|c|c|c|}
\hline \multirow{2}{*}{ Type of the additive } & \multirow{2}{*}{$\begin{array}{l}\text { Dosage of additive } \\
\text { phr }\end{array}$} & \multirow{2}{*}{$\begin{array}{l}\text { Before or after } \\
\text { aging of samples }\end{array}$} & \multicolumn{3}{|c|}{ Parameters of the vulcanization network } \\
\hline & & & $M_{c^{\prime}} \mathrm{kg} / \mathrm{mol}$ & $n \cdot 10^{-19}, \mathrm{~cm}^{3}$ & $v \cdot 10^{-5}, \mathrm{~mol} / \mathrm{cm}^{3}$ \\
\hline \multirow{2}{*}{ Without additives } & \multirow{2}{*}{-} & Before & 6530 & 11.4 & 18.5 \\
\hline & & After & 5300 & 13.0 & 24.3 \\
\hline \multirow{4}{*}{ FCA } & \multirow{2}{*}{0.2} & Before & 4200 & 13.8 & 22.9 \\
\hline & & After & 3320 & 17.4 & 28.9 \\
\hline & \multirow{2}{*}{0.2 (sonicated) } & Before & 4330 & 13.4 & 22.2 \\
\hline & & After & 2200 & 16.3 & 27.6 \\
\hline \multirow{4}{*}{ UFCA } & \multirow{2}{*}{0.2} & Before & 4240 & 13.6 & 22.6 \\
\hline & & After & 3520 & 16.4 & 27.3 \\
\hline & \multirow{2}{*}{0.2 (sonicated) } & Before & 4500 & 12.8 & 21.3 \\
\hline & & After & 3790 & 15.3 & 25.3 \\
\hline
\end{tabular}

teractions, which possibly leads to an interpenetrating network structure, complementary to the vulcanization.

Changing of the vulcanizate structure by using superfine carbon additives can have an effect not only on the thermal resistance but also on other technical properties of elastomeric compositions, which are presented in Table 6 .

T a b l e 6. Some technical properties of the tested rubber

\begin{tabular}{l|c|c|c}
\hline $\begin{array}{c}\text { Type of the } \\
\text { additive }\end{array}$ & $\begin{array}{c}\text { Dosage } \\
\text { of additive } \\
\text { phr }\end{array}$ & $\begin{array}{c}\text { Abrasion } \\
\text { resistance } \\
\mathrm{J} / \mathrm{mm}^{3}\end{array}$ & $\begin{array}{c}\text { Compression } \\
\text { set } \\
\%\end{array}$ \\
\hline $\begin{array}{l}\text { Without } \\
\text { additives }\end{array}$ & - & 32.0 & 14.0 \\
\hline FCA & $\begin{array}{c}0.2 \\
0.2 \\
\text { (sonicated) }\end{array}$ & 36.4 & 11.5 \\
\hline UFCA & $\begin{array}{c}0.2 \\
0.2\end{array}$ & 33.2 & 11.7 \\
\hline
\end{tabular}

The data show that the introduction of the additives into the elastomeric composition based on BNKS-28 allows an increase in the abrasion resistance of the rubber. Thus, the use of additives without pre-sonication improves the abrasion resistance only by $4-14 \%$, but in the case of pretreatment by $45-52 \%$. In this case, additives may help to distribute the load and temperature in the bulk of the sample, thereby reducing local stress and overheating, which leads to a breaking of crosslinks. Due to the fact that ultrasonic pretreatment results in deagglomeration and a more uniform distribution of superfine carbon additives in the elastomeric matrix, and possibly modifies the surface properties of the rubber, it allows us to significantly improve the abrasive resistance of the sample surface layer during its contact with the opposite element.

The results of the determination of the compression set demonstrated that the application of the superfine carbon additives in the elastomer compositions leads to a reduction of this parameter (by 19-22\%). It should be noted that in this case of the ultrasonic pretreatment of the additives has no significant effect on the rate of the compression set. This pattern of changes in the properties is probably due to the fact that rubbers with carbon additives are characterized themselves by a slightly higher resistance to thermo-oxidative aging and a more dense structure. These factors are the determining one for samples in the conditions of static loading under high temperature (under the conditions of the test of the compression set).

\section{CONCLUSIONS}

It was found that the introduction of the ultrasonically pretreated, superfine carbon additives to elastomeric compositions based on BNKS-28 leads to cured compounds with improved thermo-oxidative and abrasion resistance in comparison to rubbers containing the nonpretreated additives. The improvement of these rubber properties is probably due to a more uniform distribution of sonicated components and to form, besides curing network, the additional physical network due to interactions between the active centers of superfine carbon additives and polar rubber groups of rubber. As a result, the structure of interpenetrating network is formed in elastomeric matrix.

\section{REFERENCES}

[1] Rakov Je.G.: Uspehi Khimii 2001, 70, 934.

[2] Daenen M., De Fouw R.D., Hamers B. et al.: "The wondrous world of carbon nanotubes", Eindhoven University of Technology, Eindhoven 2003, p. 96.

[3] Mahfuz H., Adnan A., Rangari V.K. et al.: Applied Physics Letters 2006, 88, 083119. http://dx.doi.org/10.1063/1/2179132

[4] Pifanovsky I.S. et al.: Perspektionye materialy 2006, 2, 15.

[5] Ramsden J.J.: "Nanotechnology. An Introduction.", Chapter 9, Elsevier 2016, pp. 231-244.

[6] Shakun A., Vuorinen J., Hoikkanen M. et al.: Composites Part A: Applied Science and Manufacturing 2014, 64, 49. http://dx.doi.org/10.1016/j.compositesa.2014.04.014 
[7] Badamshina Je.R., Gafurova M.P., Jestrin Ja.I.: Uspehi Khimii 2009, 79, 1027.

[8] Badamshina Je.R., Gafurova M.P.: Vysokomolekuljarnye soedinenija 2008, 50, 1572.

[9] Gleiter H.: Acta Materialia 2000, 48, 1. http://dx.doi.org/10.1016/S1359-6454(99)00285-2

[10] Chengdong Zhang, Xiaoyan Chen: Ultrasonics Sonochemistry 2017, 34, 19. http://dx.doi.org/10.1016/j.ultsonch.2016.05.016

[11] De-Quan Y., Rochette J.-F., Sacher E.: The Journal of Physical Chemistry 2005, 109, 7788. http://dx.doi.org/10.1021/jp045147h

[12] Shutilin U.F.: "Handbook on properties and applications of elastomers: Monograph", Voronezh State Tehnological Academy 2003, p. 871.
[13] Priss Z.V., Feldshman M.S.: Kauchuk i rezina 1977, 12, 21.

[14] Kister E.V., Bulychev O.N.: "The use of ultrasound technology in Nanochemistry", Materials of X International Scientific-Technical Conference "Science and Education 2010", Murmansk, Russia, 5-12 April 2010, p. 358.

[15] Zhovner N.A. et al.: "Structure and properties of elastomer-based materials: Textbook", Branch of RosZITLP, Omsk 2003, p. 276.

[16] Dick J.S.: "Rubber Technology. Compounding and Testing for Performance", Hanser Publishers, Munich 2009, p. 561.

Received 19 X 2016.

\section{W kolejnym zeszycie ukażą się m.in. następujące artykuły:}

Z. Bartczak - Deformacja polimerów semikrystalicznych - wkład fazy krystalicznej i amorficznej (j. ang.)

T. Kozik, M. Śniechowski, W. Łużny - Wyzwanie i przygoda: dwadzieścia lat poszukiwań modelu struktury polimerowego systemu przewodzącego polianilina/kwas kamforosulfonowy prowadzących do wykorzystania metod sztucznej inteligencji ( $j$. ang.)

A. Pielesz, A. Gawłowski, J. Fabia, C. Ślusarczyk, E. Sarna-Inhibitory modelowych incydentów oparzeniowych - charakterystyka palności, badania TGA, SAXS i SEM (j. ang.)

R. Yamanaka, N. Shimizu, N. Igarashi, H. Takagi, S. Sakurai - Orientowanie cylindrycznych mikrodomen $\mathrm{w}$ kompozycjach trójblokowego kopolimeru polistyren- $b$-poli(etylen-co-butylen)- $b$-polistyren z rozcieńczalnikiem za pomoca gradientu temperatury (j. ang.)

M. Rabiej - Zastosowanie optymalizacji wielokryterialnej do rozkładu rentgenowskich krzywych dyfrakcyjnych polimerów semikrystalicznych (j.ang.)

M. Rom, J. Fabia, K. Grübel, E. Sarna, T. Graczyk, J. Janicki-Badanie możliwości biodegradacji włókien polilaktydowych w procesach oczyszczania ścieków (j.ang.)

M. Sieradzka, R. Fryczkowski, B. Fryczkowska, D. Biniaś, C. Ślusarczyk, S. Rajba, J. Janicki-Wpływ rozpuszczalników na niskotemperaturową redukcję-eksfoliację tlenku grafenu (j.ang.)

A. Gawłowski, J. Fabia, C. Ślusarczyk, T. Graczyk, A. Pielesz - Modyfikacja trudnozapalna częściowo zorientowanych włókien poli(tereftalanu etylenu) - strukturalne uwarunkowania aplikacji ( $j$. ang.)

M. Śniechowski, T. Kozik, W. Łużny - Wpływ rozpuszczalnika na anizotropię cienkich warstw polianiliny (j. ang.)

A. Gawłowski, J. Fabia, C. Ślusarczyk, A. Brzozowska-Stanuch, T. Graczyk, J. Janicki-Modyfikacja włókien z poliamidu 6 szkłem wodnym metodą kąpielową (j. ang.)

S. Paszkiewicz, A. Szymczyk, D. Pawlikowska, I. Irska, E. Piesowicz, M. Jotko, S. Lisiecki, A. Bartkowiak, M. Sieradzka, R. Fryczkowski, A. Kochmańska, P. Kochmański, Z. Rosłaniec - Poprawa właściwości barierowych nanokompozytów polimerowych opartych na modyfikowanym poli(tereftalanie etylenu) z dodatkiem pochodnych grafenu (j. ang.)

L. Wagner, M. Ponto-Wolska, Z. Raszewski, Ł. Zadrożny - Wytrzymałość na zgniatanie wkładów kompozytowych wzmocnionych włóknem szklanym umieszczonych w kanałach korzeniowych w różnej konfiguracji ilościowej (j. ang.) 